\title{
ISTIBDAL HARTA WAKAF DARI PERSPEKTIF MAZHAB SYAFI'E
}

\author{
Luqman Haji Abdullah ${ }^{*}$
}

\begin{abstract}
Among the most popular modes of developing the waqf property in many muslims countries is istibdal, that is, to exchange the original waqf property with the other one. In the Syaffi' $\bar{l}$ school of law there are discussion among their jurists as to how to develop the waqf property but Istibdal is not a popular option given that there are many rules and juristics considerations should be taken into account in implementing it and in many cases it is not allowed. Among the principles that governing the law of waqf is the subject of waqf cannot be sold or transferred to another party and this principle make istibdal is not applicable within the Syäfi' $\bar{\imath}$ school methodological framework.
\end{abstract}

Keywords: waqf, Islamic law, istibdal, Syāfi'̄ school

Senior Lecturer at Department of Fiqh and Usul, Academy of Islamic Studies, University of Malaya 


\section{PENDAHULUAN}

Wakaf adalah antara institusi kehartaan Islam yang telah banyak menyumbang ke arah pembangunan infrastruktur dan sosial masyarakat Islam. Di sepanjang sejarahnya institusi ini telah berjaya menampung institusi-institusi pendidikan, pembangunan masjid, perkuburan, perpustakaan, rumah-rumah kebajikan dan sebagainya. Dalam konteks akademik perbincangan fuqaha terhadap institusi wakaf sangat mendalam dan terperinci dan prinsip-prinsip fiqh yang dipakai juga pelbagai yang diasaskan kepada pelbagai hadis yang ada mengenai wakaf. Dalam mazhab Syafi'e perbincangan institusi ini adalah selari dengan mazhabmazhab lain yang menumpukan kepada soal prinsip hukum dan kaedah membangunkan harta wakaf yang selaras dengan prinsip hukum yang dipegang. Apa yang jelas dan dominan dalam mazhab Syafi'e ialah manhaj keterikatan dengan nas dan tidak begitu membuka ruang untuk melihat mekanisme yang lebih kreatif dalam pembangunan harta wakaf. Untuk memahami perpektif mazhab Syafi'e mengenai istibdal adalah penting untuk terlebih dahulu menyusuri prinsip-prinsip utama yang ada dalam hukum hukum wakaf dalam mazhab ini.

\section{PRINSIP-PRINSIP UTAMA WAKAF DALAM MAZHAB SYAFI'E}

\section{Prinsip-prinsip yang berkait dengan transaksi harta wakaf}

Sebelum mengkaji prinsip-prinsip utama wakaf dalam mazhab Syafi'e adalah baik untuk melihat kepada pentakrifan wakaf sebagaimana yang diberikan dalam mazhab tersebut kerana takrif yang diberikan adalah refleksi kepada prinsip-prinsip yang dipegang oleh mazhab. Al-Syāfi'‘ dalam al-Umm menggunakan istilah al-ahbōs atau al-ṣadaqāt al-muharramāt yang merujuk kepada wakaf. Beliau memberi ciri-ciri yang agak jelas dan tersusun dalam bentuk pernyataan beberapa prinsip asas wakaf dalam permulaan perbicaraan beliau terhadap hukum hakam wakaf. Beliau menyatakan: "Pemberian-pemberian yang dilafazkan oleh pemberi tanpa perlu kepada qabad (penerimaan secara fizikal) dari pihak penerima, apabila telah terkeluar lafaz 
tersebut dari pemberi maka tidak harus lagi bagi pemberi untuk memiliki semula apa yang dilafazkan tersebut dengan apa cara sekalipun. Pemberian ini adalah șadaqah yang diwakafkan kepada sesuatu golongan, atau sesuatu golongan yang disifatkan dengan ciri-ciri tertentu, dan apa-apa pemberian dalam bentuk begini yang diwakafkan kepada golongan yang disifatkan ciricirinya, sekalipun tidak dinamakan pemberian itu sebagai diharamkan (milik) maka ia adalah pemberian yang diharamkan pemilikannya atas nama al-habs." Melihat kepada teks Syafi'e tersebut boleh disimpulkan bahawa wakaf adalah suatu pemberian yang tidak boleh ditarik balik oleh pemberinya dan tidak boleh menjadi bahan pemilikan mana-mana pihak.

Ciri ini dapat difahami dengan jelas dalam penghuraian beliau yang selanjutnya selepas beliau menghuraikan hadis Rasulullah yang menasihatkan Umar supaya menahan harta (mewakafkan) dalam bentuk tanah di Khaybar yang mana beliau menegaskan bahawa bila Rasulullah mengharuskan seseorang pemilik menahan hartanya yang asal (dari pemilikan) dan diwakafkan manfaatnya maka ia bererti pemilik tersebut telah melepaskan pemilikannya ke atas harta tersebut yang mana pihak yang menerima perwakafan tersebut juga tidak mempunyai hak untuk memiliki harta asal tersebut tetapi hanya memiliki manfaatnya sahaja. Status harta ini kata beliau adalah berlainan sama sekali dengan jenis-jenis harta yang lain kerana harta yang lain berpindah milik kepada pemilik yang lain tetapi harta wakaf tidak menjadi milik sesiapa. Ia adalah sama seperti seorang pemilik yang memerdekakan seorang hamba yang mana hamba tersebut tidak lagi menjadi milik sesiapa. ${ }^{2}$

Selari dengan huraian Imam al-Syāfi‘ para fuqaha dalam mazhab Syafi'e telah mentakrifkan wakaf sebagai penahanan harta yang boleh diambil manfaat dalam bentuk pengekalan harta asal kepada pihak yang diharuskan yang mana sebarang transaksi

Al-Syāfi ‘̄̄, Muhammad bin Idrīs (1996), Mawsū‘ a al-Imām al-Syāfi ì: al-Kitāb al-Umm, Dār Qutayba, jil. 6, h. 134. Al-Habs atau kata jamaknya al-Hubus yang disebut dalam teks Syafie di atas adalah nama lain untuk wakaf. Istilah ini sebenarnya tidak begitu digunakan dalam penulisan-penulisan dalam mazhab Syafi'e tetapi popular digunakan dalam penulisan-penulisan dalam mazhab Maliki.

2 Ibid., h. 141; Al-Muzan̄̄, Abū Ibrāhīm (1990), Mukhtașar al-Muzanī, Beirut: Dār al-Ma'rifah, h. 233. 
pemindahan milik ke atas harta asal adalah dihentikan. ${ }^{3}$ Penahanan (dalam bahasa Arab disebut al-habs) di sini bererti penahanan dari segi sebarang transaksi pemindahan milik selepas sesuatu harta diwakafkan oleh pemiliknya.

Meneliti takrif-takrif dalam kitab-kitab utama mazhab Syafi'e terdapat satu persamaan yang jelas iaitu 'penahanan' sesuatu harta dari sebarang transaksi pemindahan milik samada pemilik asal atau orang lain, yang mana manfaatnya diguna secara kekal bagi tujuan kebajikan. Takrif ini sebenarnya adalah kesimpulan kepada perbincangan mengenai prinsip-prinsip wakaf sebagaimana yang diistinbatkan dari hadis riwayat Ibn Umar. Hadis tersebut menceritakan mengenai satu kawasan tanah Khaybar yang diperolehi sebagai ghanimah oleh Umar al Khattab. Beliau telah meminta pandangan Rasululllah s.a.w. mengenai yang terbaik untuk beliau lakukan kepada tanah tersebut. Rasulullah telah bersabda kepada beliau :

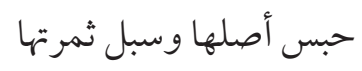

Yang bermaksud: Engkau tahan harta tersebut (iaitu tidak membuat sebarang transaksi pindah milik) dan hasilnya engkau agihkan untuk kebajikan.

Apabila Umar mendapat nasihat tersebut beliau telah membuat deklarasi bahawa tanah tersebut " tidak boleh dijual, dihibah dan dipusakakan ( لايباع ولا يوهب ولا يورث)" sebaliknya diberikan kepada golongan fakir, kaum kerabat yang memerlukan, hamba, musafir dan tetamu. ${ }^{4}$

Berdasarkan hadis di atas para fuqaha mazhab Syafi'e telah membina beberapa prinsip utama wakaf iaitu (1) harta wakaf tidak boleh di jual, dihibah dan dipusakakan (2) harta wakaf tidak boleh ditarik balik (bersifat kekal) (3) hasil atau manfaat harta wakaf

3 Ibn Hajar al-Haytamī (1983), Tuhfat al-Muhtāj fì Syarh al-Minhāj, Egypt: al-Maktaba al-Tijāriyya al-Kubrā, jil. 6, h. 235; al-Ramlī, Syams al-Dīn (1984), Nihāyat al-Muhtāaj ilā Syarh al-Minhājj, Beirūt: Dār al-Fikr, jil. 5, h. 358; al-Qalyūbī, Aḥmad bin Aḥmad (t.t.), Hāasyiyatān, Dār al-Fikr, jil. 3, h. 97: 'Umayra, Aḥmad alBarlis̄̄ (t.t.), Hāasyiyatān, Dār al-Fikr, jil 3, h. 97.

4 Muslim, Sahīh Muslim, dalam Kitāb al-Wașāyā; al-Bayhaqi, Sunan al-Kubrā, dalam Kitāb al-Waqf, jil. 6, hh. 158-159. 
adalah untuk kebajikan. Oleh kerana harta wakaf adalah demikian sifatnya maka ia disifatkan oleh para fuqaha sebagai "milik Allah". Penisbahan begini bukanlah untuk menafikan pemilikan Allah terhadap harta bukan wakaf tetapi adalah merujuk kepada sifat eksklusif yang ada pada harta wakaf yang tidak menjadi milik manusia sehingga dinisbahkan sedemikian. ${ }^{5}$

Secara dasarnya prinsip-prinsip ini adalah disepakati dalam semua mazhab yang empat, dikecualikan pandangan Imam Abu Hanifah yang berpendapat harus sesuatu wakaf itu ditarik balik, satu pandangan yang tidak diikuti dalam fatwa mazhabnya sendiri. ${ }^{6}$ Walaubagaimanapun dari segi aplikasi kepada prinsipprinsip tersebut terdapat berbagai khilaf dalam mazhab yang empat walaupun pada prinsipnya mereka bersepakat.

Kepentingan prinsip-prinsip ini dalam fiqh wakaf ialah kerana hukum-hukum yang dibina oleh para fuqaha dalam semua mazhab adalah berasas kepada prinsip-prinsip ini. Perlu dijelaskan sebahagian besar hukum-hakam wakaf adalah bersifat ijtihadi kerana nas-nas yang ada adalah sangat terhad. ${ }^{7}$ Panduan kepada para fuqaha dalam merangka dan membina hukum hakam wakaf ialah prinsip-prinsip di atas yang bersumberkan hadis Ibn Umar sebagaimana yang dinyatakan.

\section{Prinsip-prinsip yang berkait dengan subjek wakaf}

Selain dari prinsip-prinsip utama di atas beberapa prinsip lain juga perlu diambil kira iaitu yang menyentuh subjek wakaf. Hadis yang dinyatakan di atas adalah merujuk kepada tanah (harta tak alih) yang diwakafkan oleh Umar Ibn al Khattab. Oleh itu para fuqaha bersepakat mengenai keesahan wakaf tanah kerana ia berdasar kepada hadis yang sangat jelas. Walaubagaimanapun mengenai harta alih mazhab Hanafi bercanggah dengan pandangan jumhur fuqaha di mana mereka tidak mengiktiraf keesahan wakaf harta alih kecuali dalam tiga kes iaitu (1) harta yang mengikut harta tak

Al-Syarbīn̄i al-Khațīb(t.t), Mughnī al-Muhtājj, Beirut: Dār alMa'rifah, h. 502.

6 Ibn 'Ābidīn (1994), Hāasyiah Ibn 'Ābidīn, Beirut: Dar al-Kutub al'Ilmiyyah,jil. 6, h. 520.

7 Al-Zarqā' (1997), Aḥkām al-Awqāf, 'Ammān: Dār 'Ammār, h.19. 
alih seperti binatang yang berada di atas tanah yang diwakafkan (2) harta alih yang dinyata secara spesifik dalam mana-mana hadis/athar seperti pedang (3) harta alih yang telah menjadi 'uruf masyarakat mewakafkannya seperti al-Quran.

Bagi mazhab Syafi'e pewakafan harta alih adalah dibenarkan berdasarkan kepada hadis yang menyebut pengakuran Rasulullah S.A.W. kepada Khalid yang mewakafkan senjata dan baju besi beliau. Bagi fuqaha mazhab Syafi'e walaupun hadis hanya menyebut senjata perang dan baju besi tetapi penggunaan qiyas mengharuskan apa-apa jenis harta alih yang lain seperti buku, pakaian, dan sebagainya. Penggunaan qiyas oleh mazhab Syafi'e dalam isu ini menjadikan jenis-jenis harta yang boleh diwakafkan menjadi lebih luas dan banyak. Sebaliknya dalam mazhab Hanafi penjenisan harta wakaf alih adalah bergantung kepada pengamalan uruf masyarakat, satu keadaan yang sebenarnya berlainan dengan tipikal mazhab Hanafi yang selalu mengutamakan qiyas dan juga istiḩsān.

Dalam penggunaan qiyas ini juga mazhab Syafi'e hanya membataskan kepada harta alih yang bersifat kekal iaitu tidak rosak dengan sebab penggunaannya. Ertinya harta-harta seperti makanan, minuman, lilin, wangian dan sebagainya yang pengambilan manfaat darinya adalah dengan cara penggunaan yang menghabiskan zatnya adalah tidak dibenarkan. ${ }^{8}$

Dari perbincangan ini timbul isu pewakafan duit tunai. Sifat wang tunai adalah bermanfaat jika digunakan untuk pembayaran. Ini ternyata bertentangan dengan prinsip yang dibincangkan di atas yang memerlukan sesuatu harta alih yang diwakafkan itu mestilah tidak rosak dengan penggunaanya atau disebut mempunyai kualiti kekal. Dalam mazhab Syafi'e wakaf wang tunai adalah tidak dibenarkan sama sekali kerana tidak mempunyai kualiti tersebut. ${ }^{9}$ Dalam perbincangan fuqaha didapati Imam zufar dari mazhab Hanafi memberi satu cadangan bagaimana wang tunai boleh diwakafkan iaitu dengan cara dalam bentuk wang tunai itu diwakafkan untuk dijadikan modal mudārabah. Dengan cara ini wang tunai tersebut dikatakan bersifat kekal sebagai wakaf

Al-Syarbīnī al-Khațīb, op.cit., h. 418.

9 Al-Māwardī, Abū al-Hasan (1999), al-Hāầ̄ al-Kab̄̄r, Beirūt: Dār al-Kutub al-'Ilmiyyah, jil. 7, h. 519. 
manakala keuntungannya diagihkan kepada befisiari. Pandangan ini telah diamalkan dengan meluas di zaman 'Uthmaniyyah. ${ }^{10}$

Dalam mazhab Maliki ada catatan dalam al-Mudawwanah yang memberi penyelesaian wakaf wang tunai melalui cara pembentukan dana untuk pinjaman. Kaedahnya ialah wang tersebut diwakafkan dalam satu tabung untuk tujuan pinjaman kepada pihak tertentu yang mana peminjam terikat untuk membayar balik pinjaman tersebut. ${ }^{11}$ Dengan cara ini modal asal adalah tidak berkurangan dan dikatakan mempunyai kualiti kekal kerana ia dimasuk semula ke dalam tabung.

Dalam mazhab Syafi'e tidak ada perbincangan sebegini dan penggunaan helah sebagaimana yang ada dalam mazhab Hanafi dan Maliki di atas adalah menyalahi dengan prinsip dalam mazhab Syafi'e.

\section{ISTIBDAL HARTA WAKAF DALAM MAZHAB SYAFI'E}

Memahamiperbincangan prinsip-prinsipwakafdiatas sebagaimana yang dipegang dalam mazhab Syafi'e akan memudahkan untuk menilai pendirian mazhab berkenaan mengenai istibdal harta wakaf kerana ia berasas kepada prinsip-prinsip yang dijelas di atas. Istibdal ialah melakukan penukaran harta wakaf dengan cara menjual harta wakaf dan hasil jualan tersebut digunakan untuk membeli harta wakaf yang lain sebagai ganti. ${ }^{12}$

Dalam konteks mazhab Syafi'e dengan melihat kepada prinsipprinsip yang dibentang di atas istibdal adalah tidak dibenarkan kerana ia akan melibatkan pertukaran harta dan tentunya ia akan melibatkan penjualan harta tersebut atau hibah atau apa-apa yang membawa kepada pemilikan kepada sesuatu pihak. Terdapat perbincangan dalam mazhab Syafi'e yang memberi contoh masjid yang runtuh atau rosak adalah tidak diharuskan untuk dijual dan ditukar dengan tapak lain kerana ia tetap menjadi hak Allah yang tidak boleh ditukar ganti. Dalam al-Muhadhdhab ada dinyatakan:

10 Jon E. Mandaville (1979), "Usurious Piety: The Cash Waqf Controversy in the Ottomen Empire" IJMES, 10, h. 294.

11 Al-Imām Mālik (t.t), Al-Mudawwana al-Kubrā, jld. 4, h. 452.

12 Abū Zahrah (1971), Muḥādarāt F̄̄ al-Waqf, Kaherah: Dār al-Fikr al-‘Arabī, hh. 161-162. 
"Sekiranya seseorang mewakafkan masjid lalu tempat tersebut musnah dan tidak boleh didirikan sembahyang padanya ia tidak kembali menjadi milik tuannya dan tidak harus baginya membuat sebarang urusan padanya kerana ia tetap menjadi hak Allah, ia tidak kembali dimiliki oleh tuannya dengan sebab berlaku kerosakan...."13 Al-Syarbīnī ketika menghurai lafaz Minhāj menyebut dalam Mughnī al-Muhtāj: "Jika masjid runtuh dan tidak boleh dipulihkan lagi atau masjid tidak berfungsi dengan sebab kawasan tersebut telah musnah umpamanya, ia tidak kembali menjadi milik pewakaf dan tidak boleh dijual dengan apa keadaan sekalipun". ${ }^{14}$ Daripada perbincangan ini ternyata mazhab Syafi'e sangat ketat dengan prinsipnya yang tidak mengharuskan penjualan masjid dan ditukar dengan tapak lain sekalipun masjid tersebut telah runtuh. ${ }^{15}$ Bagi mereka tapak masjid tersebut masih tetap boleh digunakan untuk sembahyang dan beriktikaf. ${ }^{16}$ Segala batu bata runtuhan masjid tersebut hendaklah dijaga dan disimpan untuk digunakan untuk tujuan pembinaan semula. Walaubagaimanapun dalam kes masjid tersebut sudah tidak mempunyai harapan untuk pembinaan semula fuqaha mazhab Syafi"e mengharuskan bahan-bahan runtuhan masjid tersebut digunakan untuk tujuan pembinaan masjid di tempat lain yang berhampiran dan ini mestilah dilakukan dengan keputusan dari hakim. ${ }^{17}$ Begitu juga dengan telaga wakaf yang telah rosak, batu bata binaannya mestilah digunakan untuk telaga lain. Ini adalah untuk memastikan syarat pewakaf dijaga dan tidak diubah. ${ }^{18}$

Perbincangan di atas adalah melibatkan masjid. Dalam kategori harta yang lain terdapat perselisihan pendapat di kalangan fuqaha mazhab Syafi'e mengenai keharusan istibdal. ${ }^{19}$ Sebahagian fuqaha menegaskan bahawa harta-harta wakaf seperti pokok kayu yang telah kering atau hamparan masjid yang telah rosak

\footnotetext{
13 Al-Nawawī (t.t), al-Majmū', Kaherah: Dār Iḥyā’ al-Turāth, jil. 16, h. 329.

14 Al-Syarbīnī al-Khațīb, op.cit., h. 506.

15 Abū Zahrah, op. cit., h. 173.

16 Al-Syarbīnī al-Khațīb, op.cit.

17 Al-Qalyūbi (t.t.), Hāsyiyatān, Beirut: Dār al-Fikr, jil. 3, h. 108:

18 Al-Nawawī (2003 ), Rawdat al-Tālibīn, Arab Saudi: Dār 'Ālam alKutub, jil. 4, h.. 419.

19 Al-Nawawī, op.cit., hh. 418-419.
} 
dan tidak boleh digunakan adalah tidak boleh dijual sama sekali untuk diganti dengan pembelian lain tetapi boleh digunakan oleh benefisiari dengan tujuan-tujuan tertentu seperti sebagai bahan bakar dan sebagainya ${ }^{20}$ dan juga ada pandangan yang mengatakan ia mestilah dibiarkan begitu sahaja. ${ }^{21}$ Pandangan ini adalah selaras dengan prinsip tidak boleh dijual harta wakaf dalam apa keadaan sekalipun. Ia mesti digunakan secara yang paling maksimum selagi ada manfaat yang boleh diambil daripadanya dan bagi pandangan yang agak ketat ia mesti dibiarkan dalam keadaan rosak itu.

Walau bagaimanapun ia bukanlah pandangan yang disepakati oleh semua fuqaha mazhab Syafi'e. Terdapat pandangan lain yang dianggap muktamad dalam mazhab Syafi'e iaitu yang mengharuskan dijual harta wakaf. Contoh yang diberikan dalam kitab-kitab fiqh ialah seperti hamparan masjid yang telah rosak atau tiang-tiangnya yang telah pecah yang sudah sampai peringkat tidak boleh digunakan dan hanya sesuai untuk dibakar. Bagi pandangan ini ia boleh dijual dan harganya boleh digunakan untuk kegunaan kemaslahatan masjid. Asas yang digunakan ialah untuk mengelak pembaziran harta wakaf sekalipun ia melibatkan penjualan harta tersebut dan diganti dengan harta lain atau wangnya diaplikasikan mengikut wakaf asal. ${ }^{22}$

Dari perbincangan di atas boleh disimpulkan bahawa dalam kes masjid adalah tidak harus sama sekali dijual sekalipun masjid tersebut telah rosak dan tidak boleh dibangunkan semula. Manakala bagi harta-harta yang bersifat boleh alih terdapat perselisihan pandangan dalam kalangan fuqaha mazhab Syafi'e mengenai keharusan penjualannya dan digunakan dalam bentuk yang lain yang memberi manfaat. Melihat kepada perbincangan yang ada maka asas utama dalam perkiraan fuqaha mazhab Syafi'e ialah prinsip tidak boleh diubah status harta wakaf atau pemindahan milik kepada pihak lain. Ini sangat jelas sekali dalam pandangan mereka dalam kes masjid yang runtuh kerana bagi mereka tapak masjid masih boleh digunakan. Ertinya selagi mana boleh digunakan maka ia perlu dimaksimakan penggunaannya. Walaubagaimanapun dalam kes harta alih terdapat perbezaan dari

\footnotetext{
20 Al-Ramlī (t.t.), Nihāyat al-Muḥtāj, Kaherah: Dār al-Fikr, jil. 5, h. 395.

21 Al-Nawawī, op.cit., hal. 418.

22 Al-Ramlī, ibid.; Al-Qalyūb̄̄, op.cit.
} 
kalangan fuqaha mazhab dari sudut aplikasi prinsip-prinsip di atas.

Dalam konteks Malaysia, melihat kepada pandangan mazhab Syafi'e sebagaimana yang dibincangkan di atas adalah terlalu sukar untuk membangunkan harta wakaf terbiar di Malaysia. Di Malaysia sebelum fatwa pengharusan istibdal dikeluarkan, pandangan yang dipakai ialah berasaskan mazhab Syafi'e. ${ }^{23}$ Keadaan ini dengan jelas telah menghalang pembangunan harta wakaf berasaskan istibdal. Perkembangan yang berlaku di negara ini kemudiannya telah menyaksikan beberapa fatwa baru telah diputuskan yang mengharuskan istibdal yang berdasarkan kepada mazhab Hanafi atau Hanbali yang mana kedua-duanya berasas kepada maslahah. Bagi mereka apabila sesuatu harta wakaf itu telah binasa atau tidak berfungsi lagi kerana sebab-sebab tertentu ia boleh dijual dan harganya diguna untuk membeli harta lain sebagai ganti wakaf tersebut. Fatwa di negeri Kelantan sebagai contoh, iaitu pada tahun 1995, menyatakan dengan jelas bahwa istibdal harta wakaf adalah dibenarkan iaitu dengan mengguna pakai mazhab Hanbali. ${ }^{24}$ Fatwa yang sama dikeluarkan di Wilayah Persekutuan iaitu pada tahun 1993. ${ }^{25}$ Begitu juga dalam Muzakarah Khas Jawatankuasa Fatwa Majlis Kebangsaan Bagi Hal Ehwal Ugama Islam Malaysia Kali Ke-41 yang bersidang pada 3-4 Nov 1996 telah membincangkan Langkah-langkah Membangunkan Hartanah Waqaf MAIN Dari Perspektif Hukum. Muzakarah telah memutuskan: bahawa wakaf istibdal dan saham wakaf merupakan perkara yang amat baik dan perlu diamalkan pada masa ini kerana pembangunan sedang berjalan dengan begitu pesat sedangkan tanah-tanah waqaf, tapak masjid lama terbiar dengan begitu sahaja dan menyulitkan pihak berkuasa. Maka sudah sampai masanya segala amalan dan

23 Siti Mashitoh Mahamood (2002), Pelaksanaan Istibdal Dalam Pembangunan Harta Wakaf di Malaysia, Kuala Lumpur: Jabatan Syariah dan Undang-undang, Universiti Malaya, h. 18.

24 Sila lihat Noor Naemah Abdul Rahman, Luqman Abdullah dan Anisah Ab Ghani, Fatwa-fatwa Wakaf Di Malaysia; Analisa Khusus Di Negeri Kelantan, kertas dibentangkan dalam Konvnsyen Wakaf Kebangsaan 2006, 12-14 September 2006, Legend Hotel, anjuran Jabatan Wakaf, Zakat dan Haji, JPM.

25 Sila lihat Siti Mashitoh Mahamood (2006), Waqf in Malaysia, Kuala Lumpur; University of Malaya Press, h. 123. 
urusan mengenai waqaf pada keseluruhannya diubahsuai dengan tidak terikat kepada mazhab Syafie sahaja manakala kaedah pengurusan didasarkan kepada mazhab Hanafi umpamanya atau mana-mana mazhab atau qaul yang sesuai dengan keadaan dan masa. Selain daripada itu untuk amalan adalah perlu berhati-hati dan lebih teliti. ${ }^{26}$

Secara terperincinya, mazhab Hanafi mengemukakan tiga keadaan yang mana harta wakaf boleh diistibdal. Pertama, pewakaf telah mensyaratkan bahawa beliau boleh melakukan istibdal pada bila-bila masa beliau kehendaki. Keadaan ini diharuskan dan para fuqaha Hanafi berasaskan kepada istihsan. Kedua, istibdal boleh dilakukan bila harta wakaf tersebut sudah tidak berfungsi. Dan ketiga, terdapat potensi yang jelas bahawa istibdal akan lebih mendatangkan manfaat. Walau bagaimanpun keadaan yang pertama dan ketiga terdapat perselisihan pandangan dalam mazhab Hanafi. ${ }^{27}$ Manakala dalam mazhab Hanbali istibdal juga adalah dibenarkan berasaskan kepada keperluan pembangunan harta wakaf yang sudah tidak berfungsi. ${ }^{28}$

Kedudukan harta wakaf yang sudah tidak aktif tentunya tidak mendatangkan manfaat kepada benifisiari. Oleh itu prinsip maslahat boleh digunapakai dalam hal ini. Begitu juga prinsip 'tidak boleh dijual' di dalam hadis boleh ditafsir dengan larangan penjualan yang melibatkan pemindahan milik kepada individu. Tetapi jika penjualan itu melibatkan penggantian harta lain yang boleh mendatangkan manfaat yang lebih baik kepada benifisiari adalah tidak termasuk dalam larangan tersebut. Pemahaman begini sebenarnya dari satu aspek masih dalam kerangka mazhab Syafi'e yang boleh digunapakai dalam pembangunan harta wakaf. Jika melihat kepada keperluan pada hari ini dan kedudukan harta wakaf yang terbiar di negara ini yang perlu kepada dibangunkan pandangan dalam mazhab Syafi'e dalam kes harta alih boleh diaplikasikan juga dalam harta tak alih kerana asasnya adalah sama dan ini tentunya lebih menepati tujuan asal sesuatu wakaf. Ini bukan bererti meninggalkan nas dan mendahulukan maslahat tetapi mentafsirkan nas dengan cara yang lebih praktikal di

\footnotetext{
26 http://www.e-fatwa.gov.my/fatwa-kebangsaan/langkah-langkahmembangunkan-hartanah-waqaf-main-dari-perspektif-hukum

27 Ibn Abidin (1994), ibid., h. 583

28 Al-Bahūtī, Kasysyāâf al-Qinā', jil. 4, h. 292.
} 
samping mempertahankan prinsip yang terkandung dalam nas tersebut.

Pertembungan Mazhab Syafi'e dengan Mazhab Hanafi dan Hanbali sebenarnya boleh diharmonikan. Pemakaian nas boleh ditafsirkan dengan cara yang lebih sesuai dengan keadaan dan masa atau juga pemahaman terhadap nas mestilah dalam konteks yang berbeza.

\section{KESIMPULAN}

Istibdal harta wakaf dalam mazhab Syafi'e adalah sangat terhad dari segi pelaksanaannya kerana pentafsiran kepada prinsipprinsip wakaf adalah sangat ketat. Manhaj mazhab Syafi“e yang mengutamakan nas dan tidak membuka ruang yang luas dalam pentafsirannya telah membentuk aplikasi yang ketat dalam pelaksanaan istibdal. Dalam konteks pembangunan semasa harta wakaf pandangan begini banyak membantut dari segi pelaksanaannya. Sebagai jaln keluar adalah didapati fatwa-fatwa yang ada banyak berasaskan kepada mazhab Hanafi dan Hanbali telah membuka lebih ruang kepada pelaksanaan istibdal. 